\title{
Actinomadura flavalba sp. nov., an endophytic actinomycete isolated from leaves of Maytenus austroyunnanensis
}

\author{
Sheng Qin, Guo-Zhen Zhao, Jie Li, Wen-Yong Zhu, Li-Hua Xu \\ and Wen-Jun Li
}

Correspondence

Wen-Jun Li

wjli@ynu.edu.cn or

liact@hotmail.com

\author{
The Key Laboratory for Microbial Resources of the Ministry of Education, PR China, and Laboratory \\ for Conservation and Utilization of Bio-Resources, Yunnan Institute of Microbiology, Yunnan \\ University, Kunming 650091, PR China
}

The genus Actinomadura belongs to the family Thermomonosporaceae, which also includes the genera Actinocorallia, Spirillospora and Thermomonospora (Zhang et al., 2001). Members of the genus Actinomadura are aerobic, Gram-positive, non-acid-fast, non-motile actinomycetes that typically form non-fragmenting, extensively branched substrate mycelium and aerial hyphae that differentiate into short to long, straight, hooked or spiral spore chains with either folded, irregular, smooth, spiny or warty spores. The genus is characterized chemotaxonomically by the presence of meso-diaminopimelic acid in the cell wall, peptidoglycan structures of the acetyl type, madurose as the characteristic sugar in whole-cell hydrolysates (Goodfellow, 1989; Lechevalier \& Lechevalier, 1970) and hexahydrogenated menaquinones with nine isoprene units as the major menaquinones. The phospholipid pattern is type PI (diphosphatidylglycerol and phosphatidylinositol are present as major phospholipids) and the complex fatty acid profiles include hexadecanoic, 14methylpentadecanoic and 10-methyloctadecanoic acids as the predominant components. At the time of writing, the genus comprised 39 species, including two subspecies, with validly published names (http://www.bacterio.cict.fr/).

The GenBank/EMBL/DDBJ accession number for the 16S rRNA gene sequence of strain YIM $61435^{\top}$ is FJ157185.

An extended neighbour-joining tree based on nearly complete $16 \mathrm{~S}$ rRNA gene sequences is available as supplementary material with the online version of this paper.
As part of our long-term study on endophytic actinomycete diversity and bioactive metabolites isolated from tropical rainforest medicinal plants of Xishuangbanna, several novel species have been characterized: Dietzia schimae, Dietzia cercidiphylli, Pseudonocardia endophytica, Glycomyces scopariae, Glycomyces mayteni and Saccharopolyspora endophytica (Chen et al., 2009; Li et al., 2008; Qin et al., 2008b, 2009). Here, the characterization and classification of an Actinomadura-like isolate is described. It is proposed that this isolate represents a novel species of the genus Actinomadura.

Strain YIM $61435^{\mathrm{T}}$ was isolated from healthy leaf samples of a traditional Chinese medicinal plant, Maytenus austroyunnanensis, collected in November 2007 from a tropical rainforest in Xishuangbanna, Yunnan Province, south-west China. Samples were placed in sterile plastic bags, taken to the laboratory and stored at $4{ }^{\circ} \mathrm{C}$ before isolation. Plant samples were air-dried at room temperature after being thoroughly washed under tap water and surface-sterilized according to the five-step sterilization procedure described by Qin et al. (2008a). After that, samples were processed by the calcium carbonate enrichment method (Otoguro et al., 2001), serially diluted in sterile distilled water, spread-plated onto cellulose-proline agar $\left[2.0 \mathrm{~g}\right.$ cellulose, $0.25 \mathrm{~g} \mathrm{KNO}_{3}, 1.0 \mathrm{~g}$ proline, $0.2 \mathrm{~g}$ $\mathrm{MgSO}_{4} \cdot 7 \mathrm{H}_{2} \mathrm{O}, \quad 0.2 \mathrm{~g} \quad \mathrm{~K}_{2} \mathrm{HPO}_{4}, \quad 0.5 \mathrm{~g} \mathrm{CaCl}_{2}, \quad 10 \mathrm{mg}$ $\mathrm{FeSO}_{4} \cdot 7 \mathrm{H}_{2} \mathrm{O}$ and $15 \mathrm{~g}$ agar in $1000 \mathrm{ml}$ tap water ( $\mathrm{pH} 7.2-7.4)$ ] and incubated at $28{ }^{\circ} \mathrm{C}$ for 2 weeks. 
Extraction of genomic DNA and amplification of the 16S rRNA gene from strain YIM $61435^{\mathrm{T}}$ were done as described by Li et al. (2007). Phylogenetic analysis was performed using the software package MEGA version 3.1 (Kumar et al., 2004) after multiple alignment of data using the program CLUSTAL_X 1.8 (Thompson et al., 1997). A phylogenetic tree was constructed using the neighbour-joining (Saitou \& $\mathrm{Nei}, 1987$ ) and maximum-parsimony (Kluge \& Farris, 1969) methods. The stability of relationships was assessed by performing bootstrap analyses (Felsenstein, 1985) of the neighbour-joining data based on 1000 resamplings. The almost-complete sequence (1451 bp) of the 16S rRNA gene of strain YIM $61435^{\mathrm{T}}$ was used for phylogenetic analysis. The phylogenetic tree (Fig. 1) confirmed that this isolate was a member of the genus Actinomadura and it formed a distinct clade with Actinomadura atramentaria DSM $43919^{\mathrm{T}}$ (97.4\% 16S rRNA gene sequence similarity) with a high bootstrap value.

Cultural characteristics of the isolate were determined after 2-3 weeks at $28{ }^{\circ} \mathrm{C}$ by the methods described in the International Streptomyces Project (ISP; Shirling \& Gottlieb, 1966), as well as by examining growth on potato dextrose agar (PDA), Czapek's agar and nutrient agar (Waksman, 1967). The colony colour was determined with the ISCC-

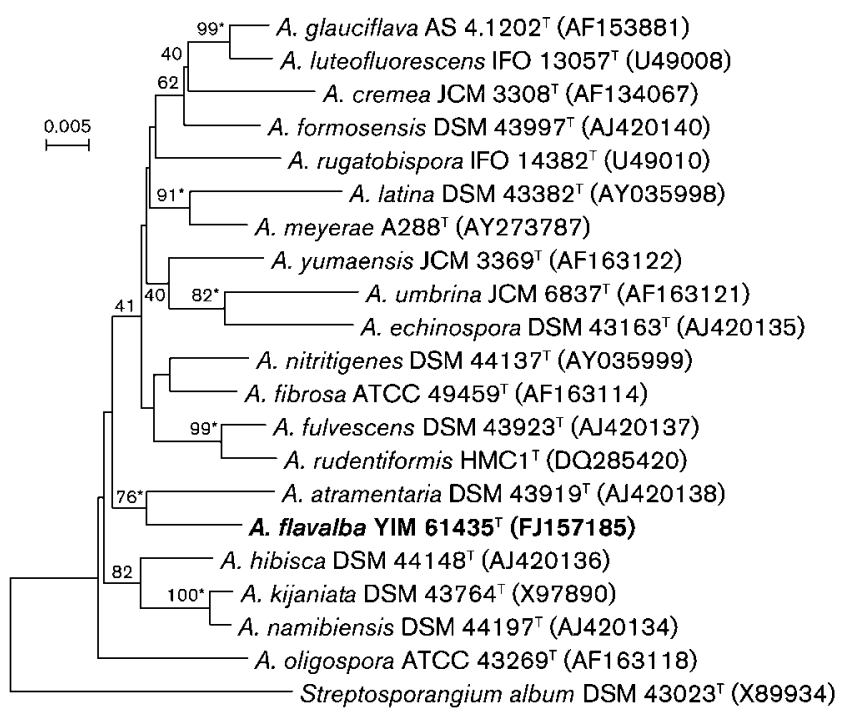

Fig. 1. Neighbour-joining phylogenetic tree based on almostcomplete 16S rRNA gene sequences showing the relationship between strain YIM $61435^{\top}$ and related members of the genus Actinomadura. Numbers at nodes are levels of bootstrap support for branch points, based on 1000 resamplings; only values $\geqslant 40 \%$ are shown. Asterisks indicate clades that were conserved when neighbour-joining and maximum-parsimony methods were used to construct phylogenetic trees. The sequence of Streptosporangium album DSM $43023^{\top}$ was used as an outgroup. Bar, 0.005 substitutions per nucleotide position. A more complete version of this tree is available as Supplementary Fig. S1 (available in IJSEM Online).
NBS colour charts (Kelly, 1964). Microscopic observation of spore chains and mycelium of strain YIM $61435^{\mathrm{T}}$ grown on ISP 2 medium for 21 days was made by light microscopy (BH2; Olympus) and scanning electron microscopy (JSM5600LV; JEOL). Growth was tested at $0,4,10,15,20$, $28,37,40,45$ and $55^{\circ} \mathrm{C}$, at $\mathrm{pH} 5.0-10.0$ (at intervals of 0.5 $\mathrm{pH}$ units) and at $0-15 \%(\mathrm{w} / \mathrm{v}) \mathrm{NaCl}$ (at intervals of $0.5 \%$ ) using ISP 2 as the basal medium. Utilization of sole carbon sources for energy and growth and decomposition of test substances were determined according to Gordon et al. (1974). Enzyme activities were determined by using API 20E and API ZYM test strips (bioMérieux) according to the manufacturer's instructions. A comparison of the phenotypic characteristics of strain YIM $61435^{\mathrm{T}}$ and its closest phylogenetic neighbour is shown in Table 1 .

Strain YIM $61435^{\mathrm{T}}$ grew well on ISP 2, ISP 3, PDA and nutrient agar, with moderate growth on ISP 4, ISP 5 and Czapek's medium. Well-developed, non-fragmenting, orange-yellow to moderate-brown substrate mycelium was formed on ISP 2, ISP 3 and Czapek's medium. No soluble pigments were observed on any of these media. Aerial mycelium was observed on all media tested. Yellowish-white aerial mycelium was formed on ISP 2, ISP 4 and ISP 5; white aerial mycelium was formed on ISP 3 and nutrient agar. Examination of spore chains on ISP 2 agar by scanning electron microscopy revealed smooth spores in long curved or hooked spore chains (Fig. 2). Optimal growth was observed at $28{ }^{\circ} \mathrm{C}$ and $\mathrm{pH}$ 7.0.

Amino acid and sugar analysis of whole-cell hydrolysates was performed according to the procedures described by Hasegawa et al. (1983). Polar lipids were extracted, examined by two-dimensional TLC and identified using published procedures (Minnikin et al., 1979; Collins \& Jones, 1980). Menaquinones were analysed by HPLC as described by Groth et al. (1997). Fatty acids were extracted, purified, methylated and quantified by GC using the standard Microbial Identification system (MIDI) (Sasser, 1990; Kämpfer \& Kroppenstedt, 1996). The cell wall diamino acid in the peptidoglycan layer of strain YIM $61435^{\mathrm{T}}$ was meso-diaminopimelic acid and the whole-cell sugars were galactose, glucose, madurose and ribose. No mycolic acids were detected in the cell wall. Phospholipids were diphosphatidylglycerol, phosphatidylglycerol and phosphatidylinositol. The predominant menaquinones were MK-9 $\left(\mathrm{H}_{4}\right)(63 \%)$ and MK-9 $\left(\mathrm{H}_{6}\right)(25 \%)$; minor components were MK- $9\left(\mathrm{H}_{2}\right)(9 \%)$ and MK- $9\left(\mathrm{H}_{8}\right)(3 \%)$. The major fatty acids found in strain YIM $61435^{\mathrm{T}}$ were iso$\mathrm{C}_{16: 0}(24.5 \%)$, 10-methyl $\mathrm{C}_{18: 0}$ [tuberculostearic acid; $14.9 \%$ ], 10-methyl $\mathrm{C}_{17: 0}(9.0 \%), \mathrm{C}_{18: 1}$ cis 9 (8.7\%), $\mathrm{C}_{16: 0}$ $(8.4 \%)$ and iso- $\mathrm{C}_{18: 0}(6.5 \%)$, with minor amounts of anteiso- $\mathrm{C}_{17: 0}$ (4.5\%), anteiso- $\mathrm{C}_{15: 0}$ (3.7\%), $\mathrm{C}_{17: 1}$ cis 9 (3.4\%), $\mathrm{C}_{17: 0}(3.2 \%), \mathrm{C}_{18: 0}(2.5 \%)$, iso- $\mathrm{C}_{17: 0}(2.2 \%)$, $\mathrm{C}_{16: 1}$ cis $9(2.2 \%)$, iso- $\mathrm{C}_{15: 0}(2.1 \%), \mathrm{C}_{15: 0}(1.4 \%), \mathrm{C}_{14: 0}$ $(1.0 \%)$ and iso- $\mathrm{C}_{14: 0}(0.9 \%)$.

The DNA G+C content of strain YIM $61435^{\mathrm{T}}$ was $71.1 \mathrm{~mol} \%$, determined according to Mesbah et al. 
Table 1. Differential characteristics of strain YIM $61435^{\top}$ and $A$. atramentaria DSM $43919^{\top}$

Data for A. atramentaria DSM $43919^{\mathrm{T}}$ were taken from Miyadoh et al. (1987) and Wink et al. (2003) unless indicated. +, Positive; -, negative; w, weak.

\begin{tabular}{|c|c|c|}
\hline Characteristic & YIM $61435^{\mathrm{T}}$ & A. atramentaria DSM $43919^{\mathrm{T}}$ \\
\hline Spore chain arrangement & Curved/hooked & Tufted and straight \\
\hline \multicolumn{3}{|l|}{ Growth on ISP 2 medium } \\
\hline Substrate mycelium & Orange-yellow & Dark brown \\
\hline Diffusible pigment & None & Inky brown \\
\hline Growth on ISP 3 medium & Good & Poor \\
\hline Growth in $5 \% \mathrm{NaCl}$ & + & $-{ }^{*}$ \\
\hline Major menaquinones & $9\left(\mathrm{H}_{4}\right)(63 \%), 9\left(\mathrm{H}_{6}\right)(25 \%)$ & $9\left(\mathrm{H}_{6}\right)(69 \%), 9\left(\mathrm{H}_{4}\right)(14 \%)$ \\
\hline Utilization of glucose, fructose, inositol and sucrose & + & $-*$ \\
\hline Hydrolysis of starch & + & $-*$ \\
\hline Liquefaction of gelatin & + & $-{ }^{*}$ \\
\hline \multicolumn{3}{|l|}{ API ZYM tests } \\
\hline Cystine arylamidase & $\mathrm{w}$ & - \\
\hline \multicolumn{3}{|l|}{ API $20 \mathrm{E}$ tests } \\
\hline Arginine dihydrolase & + & - \\
\hline Lysine decarboxylase & + & - \\
\hline DNA $G+C$ content $(\mathrm{mol} \%)$ & 71.1 & 72 \\
\hline
\end{tabular}

${ }^{\star}$ Data from this study.

(1989). Levels of DNA-DNA relatedness were determined according to the fluorometric microwell method (Ezaki et al., 1989; He et al., 2005). DNA-DNA hybridization studies revealed low relatedness values of $21.5 \pm 1.8 \%$ with its closest phylogenetic neighbour, A. atramentaria DSM $43919^{\mathrm{T}}$, which is much lower than the threshold value of $70 \%$ recommended for the delineation of genomic species (Stackebrandt \& Goebel, 1994). This clearly indicates that strain YIM $61435^{\mathrm{T}}$ represents a different genomic species.

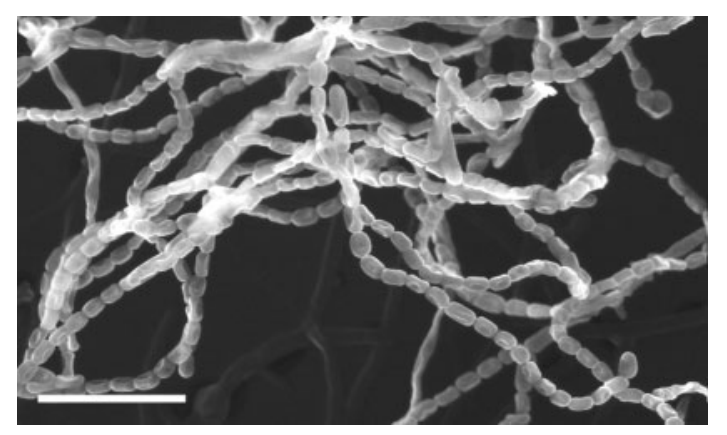

Fig. 2. Scanning electron micrograph of strain $\mathrm{YIM} 61435^{\top}$ grown on ISP 2 medium at $28{ }^{\circ} \mathrm{C}$ for 3 weeks. Bar, $5 \mu \mathrm{m}$.
There were many obvious differences between strain YIM $61435^{\mathrm{T}}$ and $A$. atramentaria DSM $43919^{\mathrm{T}}$, e.g. differences in growth characteristics on ISP 2 and ISP 3 media, spore chain ornamentation, utilization of carbon sources and the major menaquinones. Based on the broad range of genotypic and phenotypic data, strain YIM $61435^{\mathrm{T}}$ is a member of the genus Actinomadura and represents a novel species, for which the name Actinomadura flavalba sp. nov. is proposed.

\section{Description of Actinomadura flavalba sp. nov.}

Actinomadura flavalba (fla.val'ba. L. adj. flavus -a -um yellow; L. adj. albus -a -um white; N.L. fem. adj. flavalba yellowish-white, referring to the colour of the aerial mycelium).

Aerobic, Gram-positive, non-acid-alcohol-fast, non-motile actinomycete. Forms well-developed, branched, non-fragmenting substrate mycelium. Abundant aerial mycelium is present, which differentiates into curved or hooked chains of spores (spore size $0.5-0.7 \times 0.8-1.2 \mu \mathrm{m}$ ). The spore surface is smooth. Good growth occurs on ISP 2, ISP 3, PDA and nutrient agar. Moderate growth occurs on ISP 4, ISP 5 and Czapek's medium. Yellowish-white aerial mycelium is formed on ISP 2, ISP 4 and ISP 5 media. No diffusible pigments are produced on any of the media 
tested. Temperature range for growth is $15-37{ }^{\circ} \mathrm{C}$, with optimal growth at $28{ }^{\circ} \mathrm{C}$. Grows in $0-10 \% \mathrm{NaCl}$ and at pH 6.0-8.0. Decomposes adenine, aesculin, casein, gelatin, hypoxanthine, starch and xanthine. Does not decompose Tween 80 . Gelatin liquefaction is observed. $\mathrm{H}_{2} \mathrm{~S}$ is not produced. Nitrate reduction is negative. Dulcitol, erythritol, D-fructose, D-galactose, glucose, inositol, lactose, maltose, L-rhamnose, D-ribose, sorbitol, sucrose and trehalose are utilized as sole carbon sources, but Darabinose, cellobiose, mannitol, D-mannose, raffinose, Lsorbose, xylitol and D-xylose are not utilized. Other physiological properties are indicated in Table 1. Type III/B cell wall (meso-diaminopimelic is the diagnostic diamino acid and madurose is the characteristic sugar). Predominant menaquinones are MK-9 $\left(\mathrm{H}_{4}\right)$ and MK$9\left(\mathrm{H}_{6}\right)$, with MK-9 $\left(\mathrm{H}_{2}\right)$ and MK-9 $\left(\mathrm{H}_{8}\right)$ as minor components. The phospholipids are diphosphatidylglycerol, phosphatidylglycerol and phosphatidylinositol. Major fatty acids $\left(>5.0 \%\right.$ of the total) are iso- $\mathrm{C}_{16: 0}, 10$-methyl $\mathrm{C}_{18: 0}$, 10-methyl $\mathrm{C}_{17: 0}, \mathrm{C}_{18: 1}$ cis $9, \mathrm{C}_{16: 0}$ and iso- $\mathrm{C}_{18: 0}$.

The type strain is YIM $61435^{\mathrm{T}}\left(=\mathrm{DSM} 45200^{\mathrm{T}}=\right.$ CCTCC AA $208017^{\mathrm{T}}$ ), isolated from surface-sterilized leaves of Maytenus austroyunnanensis collected from the tropical rainforest in Xishuangbanna, Yunnan Province, south-west China. The DNA G + C content of strain YIM $61435^{\mathrm{T}}$ is $71.1 \mathrm{~mol} \%$.

\section{Acknowledgements}

The authors are grateful to Professor Hans-Peter Klenk for kindly providing Actinomadura atramentaria DSM $43919^{\mathrm{T}}$. This research was supported by the National Basic Research Program of China (project no. 2004CB719601), the Yunnan Provincial International cooperative Program (no. 2005GH21), the Key Project of Chinese Ministry of Education (no. 206139), the National Natural Science Foundation of China (project no. 30560001) and the Yunnan Provincial Education Commission Scientific Research Foundation (no. 08J0008). W.-J.L. was supported by the Program for New Century Excellent Talents in University.

\section{References}

Chen, H.-H., Qin, S., Li, J., Zhang, Y.-Q., Xu, L.-H., Jiang, C.-L., Kim, C.-J. \& Li, W.-J. (2009). Pseudonocardia endophytica sp. nov., isolated from the pharmaceutical plant Lobelia clavata. Int $J$ Syst Evol Microbiol 59, 559-563.

Collins, M. D. \& Jones, D. (1980). Lipids in the classification and identification of coryneform bacteria containing peptidoglycans based on 2,4-diaminobutyric acid. J Appl Bacteriol 48, 459-470.

Ezaki, T., Hashimoto, Y. \& Yabuuchi, E. (1989). Fluorometric deoxyribonucleic acid-deoxyribonucleic acid hybridization in microdilution wells as an alternative to membrane filter hybridization in which radioisotopes are used to determine genetic relatedness among bacterial strains. Int J Syst Bacteriol 39, 224-229.

Felsenstein, J. (1985). Confidence limits on phylogenies: an approach using the bootstrap. Evolution 39, 783-791.

Goodfellow, M. (1989). Maduromycetes. In Bergey's Manual of Systematic Bacteriology, vol. 4, pp. 2509-2551. Edited by S. T. Williams, M. E. Sharpe \& J. G. Holt. Baltimore: Williams \& Wilkins.
Gordon, R. E., Barnett, D. A., Handerhan, J. E. \& Pang, C. H.-N. (1974). Nocardia coeliaca, Nocardia autotrophica, and the nocardin strain. Int J Syst Bacteriol 24, 54-63.

Groth, I., Schumann, P., Rainey, F. A., Martin, K., Schuetze, B. \& Augsten, K. (1997). Demetria terragena gen. nov., sp. nov., a new genus of actinomycetes isolated from compost soil. Int J Syst Bacteriol 47, 1129-1133.

Hasegawa, T., Takizawa, M. \& Tanida, S. (1983). A rapid analysis for chemical grouping of aerobic actinomycetes. J Gen Appl Microbiol 29, 319-322.

He, L., Li, W., Huang, Y., Wang, L., Liu, Z., Lanoot, B., Vancanneyt, M. \& Swings, J. (2005). Streptomyces jietaisiensis sp. nov., isolated from soil in northern China. Int J Syst Evol Microbiol 55, 1939-1944.

Kämpfer, P. \& Kroppenstedt, R. M. (1996). Numerical analysis of fatty acid patterns of coryneform bacteria and related taxa. Can J Microbiol 42, 989-1005.

Kelly, K. L. (1964). Inter-Society Color Council - National Bureau of Standards Color Name Charts Illustrated with Centroid Colors. Washington, DC: US Government Printing Office.

Kluge, A. G. \& Farris, J. S. (1969). Quantitative phyletics and the evolution of anurans. Syst Zool 18, 1-32.

Kumar, S., Tamura, K. \& Nei, M. (2004). MEGA3: integrated software for molecular evolutionary genetics analysis and sequence alignment. Brief Bioinform 5, 150-163.

Lechevalier, M. P. \& Lechevalier, H. A. (1970). Chemical composition as a criterion in the classification of aerobic actinomycetes. Int J Syst Bacteriol 20, 435-443.

Li, W.-J., Xu, P., Schumann, P., Zhang, Y.-O., Pukall, R., Xu, L.-H., Stackebrandt, E. \& Jiang, C.-L. (2007). Georgenia ruanii sp. nov., a novel actinobacterium isolated from forest soil in Yunnan (China), and emended description of the genus Georgenia. Int J Syst Evol Microbiol 57, 1424-1428.

Li, J., Zhao, G.-Z., Zhang, Y.-O., Klenk, H.-P., Pukall, R., Qin, S., Xu, L.-H. \& Li, W.-J. (2008). Dietzia schimae sp. nov. and Dietzia cercidiphylli sp. nov., from surface-sterilized plant tissues. Int J Syst Evol Microbiol 58, 2549-2554.

Mesbah, M., Premachandran, U. \& Whitman, W. B. (1989). Precise measurement of the $\mathrm{G}+\mathrm{C}$ content of deoxyribonucleic acid by highperformance liquid chromatography. Int J Syst Bacteriol 39, 159-167.

Minnikin, D. E., Collins, M. D. \& Goodfellow, M. (1979). Fatty acid and polar lipid composition in the classification of Cellulomonas, Oerskovia and related taxa. J Appl Bacteriol 47, 87-95.

Miyadoh, S., Amano, S., Tohyama, H. \& Shomura, T. (1987). Actinomadura atramentaria, a new species of the Actinomycetales. Int J Syst Bacteriol 37, 342-346.

Otoguro, M., Hayakawa, M., Yamazaki, T. \& limura, Y. (2001). An integrated method for the enrichment and selective isolation of Actinokineospora spp. in soil and plant litter. J Appl Microbiol 91, 118130.

Qin, S., Wang, H.-B., Chen, H.-H., Zhang, Y.-O., Jiang, C.-L., Xu, L.-H. \& Li, W.-J. (2008a). Glycomyces endophyticus sp. nov., an endophytic actinomycete isolated from the root of Carex baccans Nees. Int J Syst Evol Microbiol 58, 2525-2528.

Qin, S., Li, J., Zhao, G.-Z., Chen, H.-H., Xu, L.-H. \& Li, W.-J. (2008b). Saccharopolyspora endophytica sp. nov., an endophytic actinomycete isolated from the root of Maytenus austroyunnanensis. Syst Appl Microbiol 31, 352-357.

Qin, S., Chen, H. H., Klenk, H. P., Zhao, G. Z., Li, J., Xu, L. H. \& Li, W. J. (2009). Glycomyces scopariae sp. nov. and Glycomyces mayteni sp. nov., isolated from two medicinal plants in China. Int J Syst Evol Microbiol 59, 1023-1027. 
Saitou, N. \& Nei, M. (1987). The neighbor-joining method: a new method for reconstructing phylogenetic trees. Mol Biol Evol 4, 406-425.

Sasser, M. (1990). Identification of bacteria by gas chromatography of cellular fatty acids, MIDI Technical Note 101. Newark, DE: MIDI Inc.

Shirling, E. B. \& Gottlieb, D. (1966). Methods for characterization of Streptomyces species. Int J Syst Bacteriol 16, 313-340.

Stackebrandt, E. \& Goebel, B. M. (1994). Taxonomic note: a place for DNA-DNA reassociation and $16 \mathrm{~S}$ rRNA sequence analysis in the present species definition in bacteriology. Int J Syst Bacteriol 44, 846849.

Thompson, J. D., Gibson, T. J., Plewniak, F., Jeanmougin, F. \& Higgins, D. G. (1997). The CLUSTAL_X windows interface: flexible strategies for multiple sequence alignment aided by quality analysis tools. Nucleic Acids Res 25, 4876-4882.

Waksman, S. A. (1967). The Actinomycetes. A Summary of Current Knowledge. New York: Ronald Press.

Wink, J., Kroppenstedt, R. M., Seibert, G. \& Stackebrandt, E. (2003). Actinomadura namibiensis sp. nov. Int J Syst Evol Microbiol 53, 721724.

Zhang, Z., Kudo, T., Nakajima, Y. \& Wang, Y. (2001). Clarification of the relationship between the members of the family Thermomonosporaceae on the basis of 16S rDNA, 16S-23S rRNA internal transcribed spacer and $23 \mathrm{~S}$ rDNA sequences and chemotaxonomic analyses. Int J Syst Evol Microbiol 51, 373-383. 